\title{
The Determinants of Environmental Information Disclosure in Vietnam Listed Companies
}

\author{
Thi Le Hang NGUYEN*, Thi Thu Hien NGUYEN**, Thi Thanh Huyen NGUYEN***, \\ Thi Hong Anh LE ${ }^{* * * *}$,Van Cong NGUYEN ${ }^{* * * * *}$
}

Received: December 5, 2019 Revised: December 11, 2019 Accepted: December 18, 2019

\begin{abstract}
Environmental pollution and climate change in Vietnam are now becoming a major concern. This situation is increasing the pressure on the companies to improve their social responsibility in production and business activities and disclose the environmental information to meet the requirements of stakeholders. This study investigates the internal and external factors of the company that affects the environmental information disclosure of listed companies on the Vietnam stock market as business sector, firm size, corporate manager perceptions, profitability, financial leverage, community pressure, pressures from stakeholders, government pressure influencing environmental information disclosure. Analytical data collected through the survey of 120 listed companies on the Ho Chi Minh City Stock Exchange (HOSE). By testing Cronbach's Alpha, exploratory factor analysis (EFA) and logistic regression analysis, the results of the study show that the level of environmental information disclosure of listed companies on the stock market in Vietnam depends heavily on government regulations, followed by the pressure from stakeholders, community pressure, views of business managers, companies size, business sector, and particularly profitability and financial leverage factors that have a negative relationship with environmental information disclosure.
\end{abstract}

Keywords: Environmental Information, Information Disclosure, Environmental Report, Vietnam Listed Companies.

JEL Classification Code: D22, G14, M14, O13, O44.

\section{Introduction}

According to the annual Environmental Performance Index (EPI), Vietnam currently ranks among the top 10 air-

\footnotetext{
${ }^{\star}$ First Author. Faculty of Economics and Accounting, Quy Nhon University, Quy Nhon, Vietnam. Email: ntlhang@qnu.edu.vn **Faculty of Industrial University of Ho Chi Minh City (IUH), Hochiminh City, Vietnam. Email: nguyenthuhien@iuh.edu.vn

*** Faculty of Environmental, Climate Change and Urban Studies, The National Economics University (NEU), Vietnam.

Email: huyennt@neu.edu.vn

****Faculty of Law, The National Economics University (NEU), Vietnam. Email: honganhneu@email.com

${ }^{* * * *}$ Corresponding Author. Professor, School of Accounting and Auditing, The National Economics University (NEU), Vietnam. [Postal Address: 207 Giai Phong, Dong Tam, Hai Ba Trung, Hanoi, 113068, Vietnam] Email: anhcongtuan@gmail.com or congnguyen@neu.edu.vn

(c) Copyright: Korean Distribution Science Association (KODISA)

This is an Open Access article distributed under the terms of the Creative Commons Attribution NonCommercial License (https://creativecommons.org/licenses/by-nc/4.0/) which permits unrestricted noncommercial use, distribution, and reproduction in any medium, provided the original work is properly cited.
}

polluting countries in Asia and ranks 132/180 countries on 24 performance indicators across ten issue categories covering environmental health and ecosystem vitality Yale University (2018). After many lawsuits on environmental pollution of companies such as the lawsuit against Vedan company in 2009, Formosa company in 2016, etc; Vietnamese government, organizations that work for the environment, local community, companies, investors, etc increasingly aware and more concerned about environmental issues. Therefore, the pressure of environmental information disclosure on listed companies has been increased and companies must carry out accountability for environmental information on financial statements to meet the different requirements of stakeholders. The environmental information is published and presented in the annual financial statements or midyear report. These information are required according to the Ministry of Finance (2015), including: material resource management, energy consumption, water consumption, complying with the law on environmental protection. 
The purpose of this study is to identify factors that affect the environmental information disclosure of listed companies on the Vietnam stock market. To do this study, the authors based on the audited and published annual reports by the stock market listed companies at the Ho Chi Minh Stock Exchange. The study selects 120 companies that disclosed environmental information including full disclosure of information items and incomplete disclosure of information items as regulations to send questionnaires. The result of the survey has 106 companies with valid questionnaires, reaching a rate of $88.33 \%$. This study contributes to a series of empirical studies on environmental information disclosure in Vietnam, an issue paid great attention by the Vietnamese government for Vietnam's green and sustainable economic development.

The structure of this study consists of five parts; the next section presents the literature review; the third section presents research methodology including research hypothesis, descriptions of research variables and selection of research samples, gathering data; the fourth section shows the research results; the fifth section discusses research results and the final section is the main conclusions of the study as well as demonstrating the limitations and directions of future research.

\section{Literature Review}

Referring to the study of factors affecting environmental information disclosure, there have many types of researches in terms of both theoretical and empirical. In terms of the theoretical framework, studies have given many theoretical frameworks related to environmental information disclosure such as Stakeholder theory of Robertson and Nicholson (1996), Legal Theory of Patten (1992), Wilmshurst and Frost (2000) or Institutional theory of Cormier and Gordon (2001), etc. These studies aim to encourage countries to enact mandatory regulations in order to increase pressure on environmental information disclosure for companies to meet the different requirements of stakeholders. The government should have strong sanctions enough to implement environmental policies in the context of environmental issues that have not been properly and uniformly addressed among countries.

In terms of empirical research, many studies have concluded that the high or low environmental information disclosure is related to the size of the companies and environmentally sensitive industries (Aerts, Cormier, \& Magnan, 2008), community concerns and public policy pressure (Deegan, Rankin, \& Tobin, 2002; Neu, Warsame, \& Pedwell, 1998; Patten, 2002), the antecedents of organizational commitment for adopting corporate environmental responsibility and green practices (Lee, Kim,
\& Kim, 2018) and its pollution propensity increases, outsiders' knowledge of its environmental liabilities increases, and the risk of incurring proprietary costs decreases (Li, Richardson, \& Thornton, 1997). At the same time, Robertson and Nicholson (1996) showed that there were differences between industries in the environmental information disclosure for stakeholders or Deegan and Gordon (1996) analyzed the environmental information disclosure of 197 companies in Australia between 1980 and 1991, they show that environmentally sensitive companies have a trend of disclosing more environmental information than other companies; and according to this study, companies size also has a significant influence on the quantity and quality of the environmental information disclosure.

Zhang, Guo, Li, and Wang (2008) conducted a study of 128 listed chemical companies in the stock market in China from 2003 to 2005, the results of this study show that companies size is the factor that has the greatest influence on the level of environmental information disclosure; because big companies carry out many business activities, there is a great impact on the society and the environment. Then, they are more pressure from the community and supervision of state management agencies than then smallscale enterprises. Thus, these companies increase environmental information disclosure to create a good image with society and stakeholders. Similarly this point of view, the studies of Haldma and Lääts (2002), Chenhall (2003), Cadez and Guilding (2008), etc. also indicate that large-scale companies have higher resources and can apply accounting techniques better than small companies, so the environmental information disclosure is better than small companies.

A study by Huang and Kung (2010) at Taiwanese firms listed on the Taiwan Stock Exchange shows that the level of environmental disclosure is significantly affected by stakeholder groups' demands. Besides, Lehman (1983), Guthrie and Parker (1990), Gray, Kouhy, and Lavers (1995) show that the environmental information disclosure by companies is due to social pressure. Information disclosure is to meet social expectations rather than a willingness of companies, especially companies operate in environmentally sensitive companies such as oil, gas and chemical industries, etc. Another research direction is that the environmental information disclosure will help companies gain market benefits as well as the ability get profits from investing in environmental improvement activities (Gelb \& Zarowin, 2002; Shane \& Spicer, 1983). Therefore, companies tend to provide more environmental information in their reports.

From the literature review of the above studies shows that environmental information disclosure of companies in general and listed companies, public-interest companies in 
particular are influenced by many factors such as government regulations, community pressure, pressure of stakeholders on business activities of companies, companies size, the awareness of managers in attracting investment and increasing market share and profits, etc.

\section{Research Method}

\subsection{Hypothesis and Research Model}

\subsubsection{Business Sectors (BS)}

Companies in different business sectors face different levels of pressure of environmental information disclosure such as the environmental information disclosure of a company operating in the chemical industry must be more than one company in the service sector. Cormier and Gordon (2001) show that companies in environmentally sensitive industries, including petroleum, chemicals and paper products, etc. tend to disclose more environmental information to reduce environmental concerns from governments and communities. Similarly, this point is found in Malarvizhi and Matta (2016), Deegan and Gordon (1996), Patten (1992). Thus, the first hypothesis is set to:

Hypothesis 1 (H1): Environmentally sensitive business sector has a positive relationship with environmental information disclosure of listed companies on the Vietnam stock market.

\subsubsection{Companies Size (CS)}

Companies size is a factor determined by many studies that have significant influence on environmental information disclosure (Zhang, Guo, Li, \& Wang, 2008; Patten, 2002). Studies suggest that larger companies have disclosed more environmental information. Because of the abundant financial resources, the management and technical staff have higher qualifications, it is easy to implement environmental information disclosure to meet the requirements of government and society. Zhang, Guo, Li, and Wang (2008); Deegan and Gordon (1996) also support this view. Therefore, the second hypothesis is set up as follows:

Hypothesis 2 (H2): Companies size has a positive relationship with environmental information disclosure of listed companies on the Vietnam stock market.

\subsubsection{Awareness of Business Managers (ABM)}

Lee, Jung, and Kim (2005) and Kokubu and Nashioka (2005) demonstrated that the awareness of business managers is an important factor in implementing environmental accounting in Japan and Korea. The awareness of business managers about the environment will determine the choice of policy, developing orientation related to the environment in the business activities of companies. Spencer, Adams, and Yapa (2013) show that business leaders have a good awareness of environmental issues, they tend to adopt an accounting system to be able to provide information related to the environment. The above analysis shows that the awareness of business managers affects environmental information disclosure. The research of Bebbington, Gray, Thomson, and Walters (1994) also supports this opinion. Thus, the third hypothesis is set up as follows:

Hypothesis 3 (H3): Awareness of business managers has a positive relationship with environmental information disclosure of listed companies on the Vietnam stock market.

\subsubsection{Profitability (P)}

Companies will implement environmental information disclosure to show their position with investors and financial institutions, etc. The environmental information disclosure will help companies gain market benefits as well as increasing the profitability from investment in environmental improvement activities. Therefore, companies tend to provide more environmental information in their reports. Gelb and Zarowin (2002), Shane and Spicer (1983) provided evidence of information disclosure related to estimated future earnings and Saha and Akter (2012) demonstrated a positive relationship between environmental information disclosures and companies' profits. Neu, Warsame, and Pedwell (1998), Neu, Warsame, and Pedwell (1996), Zhang, Guo, Li, and Wang (2008) also support this point of view. Hence, the fourth hypothesis is set up as follows:

Hypothesis 4 (H4): The profitability of companies has a positive relationship with the environmental information disclosure of listed companies on the Vietnam stock market.

\subsubsection{Financial Leverage (FL)}

Li, Richardson, and Thornton (1997) studied the disclosure of environmental liabilities, they show that managers have environmental information disclosure strategies and environmental information tends to increase when companies can cause more pollution, and when stakeholders become more aware of the environmental liabilities of companies. Zhang, Guo, Li, and Wang (2008) demonstrated that financial leverage also has an impact on environmental information disclosure. Therefore, the fifth hypothesis is set up as follows:

Hypothesis 5 (H5): Financial leverage has a positive relationship with the environmental information disclosure 
of listed companies on the Vietnam stock market.

\subsubsection{Community Pressure (CP)}

Social and environmental responsibility is an important driving force to change companies' activities, including an accounting system to try to meet community expectations. The enterprise accounting system will change in order to enhance the interpretation of environmental information to meet community requirements or divert community attention in adverse environmental situations Deegan and Rankin (1996), Liu and Anbumozhi (2009), Patten (1992); Tilt (1994). Qian, Burritt, and Monroe (2011) also agree with this view. Thus, the sixth hypothesis is as follows:

Hypothesis 6 (H6): Community pressure has a positive relationship with environmental information disclosure of listed companies on the Vietnam stock market.

\subsubsection{Stakeholders Pressure (SP)}

Normally, companies need to meet the environmental information demand for stakeholders to improve and enhance relationships with stakeholders, as well as building their good image and brand. Stakeholders have a different role and impact on the production and business activities of companies; Different stakeholders require different types of environmental information. For example, business managers need information about costs, revenues and profits; environmental organizations and communities often require information about environmental impacts; while tax authorities, shareholders and investors need relevant information about assets and environmental liabilities. Similarly, studies of Jamil, Mohamed, Muhammad, and Ali (2015), Deegan and Gordon (1996) found evidence of a correlation between environmental information disclosure and environmental advocacy organizations. Therefore, the seventh hypothesis is set up as follows:

Hypothesis 7 (H7): Stakeholders' pressure has a positive relationship with the level of environmental information disclosure of listed companies on Vietnam's stock market.

\subsubsection{Government Pressure (GP)}

Government pressure is explained as the pressure to force businesses to comply with the current environmental regulations; pressure from the government and regulatory agencies can intervene and affect companies' compliance with the current environmental regulations. Therefore, in order to survive and develop, businesses should comply with the official mechanisms imposed by the government (DiMaggio \& Powell, 1983).

This view also found in Pondeville, Swaen, and Rongé (2013); Qian, Burritt, and Monroe (2011). In Vietnam, there are the tightening regulations from the government, the state management agencies on the environment, especially for environmentally sensitive industries through regulations such as: (1) Law on environmental protection No. 55/2014/QH13, issued on June 23, 2014 (National Assembly of the Socialist Republic of Vietnam, 2014); (2) Circular No. 38/2015/TT-BTNMT on environmental rehabilitation and restoration in mineral exploitation activities, issued on June 30, 2015 (Ministry of Natural Resources and Environment, 2019) and other legal documents. Therefore, the eighth hypothesis here is that:

Hypothesis 8 (H8): Government pressure is positively related to environmental information disclosure of listed companies on Vietnam's stock market.

Based on the research hypotheses, the authors proposed the research model is multivariate regression model with the dependent variable of environmental information disclosure and independent variables mentioned in each research hypothesis above as follows:

$\mathrm{Y}=\alpha 0+\alpha 1 . \mathrm{BS}+\alpha 2 . \mathrm{CS}+\alpha 3 . \mathrm{ABM}+\alpha 4 . \mathrm{P}+\alpha 5 . \mathrm{FL}+$ $\alpha 6 . \mathrm{CP}+\alpha 7 . \mathrm{SP}+\alpha 8 . \mathrm{GP}+\varepsilon$

Where: $\alpha 0, \alpha 1, \alpha 2, \alpha 3, \alpha 4, \alpha 5, \alpha 6, \alpha 7$ and $\alpha 8$ are coefficients

\section{$\varepsilon$ is error}

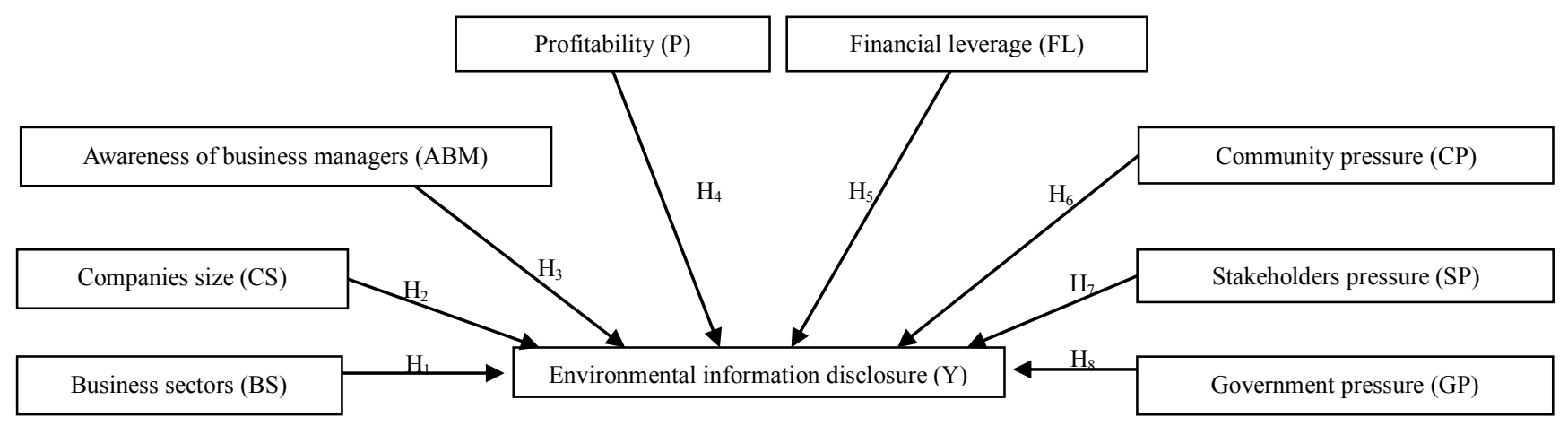

Figure 1: Overview of the research model 


\subsection{Variables of the Research Model}

To serve for the questioning and answering process, the authors used the Likert scale (5 choices). Levels of environmental information disclosure and factors affecting environmental information disclosure on this scale are as follows: 1 = "very low", 2 = "low", 3 = "average ', 4 = "high", 5 = "very high".
Based on the regulations of the Government of Vietnam on guidelines for environmental information disclosure in Ministry of Finance (2015) and inheriting previous studies, as well as consulting experts to match in the Vietnamese context, the authors designed the observed measurement variables to publish environmental information (dependent variable) as follows.

Table 1: Observed variables measuring environmental information disclosure

\begin{tabular}{|l|c|l|}
\hline \multicolumn{1}{|c|}{ Observed variables } & Encryption & \multicolumn{1}{c|}{ Source } \\
\hline 1. Management of raw materials & Y1 & GRI (2018); Ministry of Finance (2015) \\
\hline 2. Energy consumption & Y2 & GRI (2018); Ministry of Finance (2015) \\
\hline 3. Water consumption & Y3 & $\begin{array}{l}\text { Ministry of Finance (2015); United Nations (2002); Wiseman (1982); } \\
\text { Zeng S. X., Xu, Yin, \& Tam (2012) }\end{array}$ \\
\hline 4. Compliance with the law on environmental protection & Y4 & Ministry of Finance (2015); United Nations (2002); Wiseman (1982) \\
\hline
\end{tabular}

Table 2: Observed variable for factors affecting (independent variables) environmental information disclosure

\begin{tabular}{|c|c|c|c|c|}
\hline TT & Factors & Observed variables & Encryption & Source \\
\hline 1 & Business sectors & Business area & BS & $\begin{array}{l}\text { Cormier \& Gordon (2001); Deegan \& Gordon (199 } \\
\text { 6); Malarvizhi \& Matta (2016); Patten (1992) }\end{array}$ \\
\hline 2 & Companies size & Business scale & $\mathrm{CS}$ & $\begin{array}{l}\text { Deegan \& Gordon (1996); Patten (2002); Zhang, Gu } \\
\text { o, Li, \& Wang (2008) }\end{array}$ \\
\hline \multirow{4}{*}{3} & \multirow{4}{*}{$\begin{array}{l}\text { Awareness of } \\
\text { business manager } \\
\text { s }\end{array}$} & 1. Meeting legal responsibilities & $\mathrm{ABM} 1$ & \multirow{4}{*}{$\begin{array}{l}\text { Bebbington, Gray, Thomson, \& Walters (1994); Kok } \\
\text { ubu \& Nashioka (2005); Lee, Jung, \& Kim, (2005); } \\
\text { Spencer, Adams, \& Yapa, (2013) }\end{array}$} \\
\hline & & 2. Satisfying the explanation requirement & ABM 2 & \\
\hline & & 3. Accurate environmental cost information & $\mathrm{ABM} 3$ & \\
\hline & & $\begin{array}{l}\text { 4. Provide a proper and reasonable } \\
\text { viewpoint of operation }\end{array}$ & $\mathrm{ABM} 4$ & \\
\hline 4 & Profitability & Profitability & $\mathrm{P}$ & $\begin{array}{l}\text { Deegan \& Gordon (1996); Gelb \& Zarowin (2002); } \\
\text { Neu, Warsame, \& Pedwell (1998); Saha \& Akter (20 } \\
\text { 12); Shane \& Spicer (1983); Zhang, Guo, Li, \& Wan } \\
\text { g (2008) }\end{array}$ \\
\hline 5 & $\begin{array}{l}\text { Financial leverag } \\
\mathrm{e}\end{array}$ & Financial leverage & FL & $\begin{array}{l}\text { Li, Richardson, \& Thornton (1997); Zhang, Guo, Li, } \\
\text { \& Wang (2008) }\end{array}$ \\
\hline \multirow{2}{*}{6} & \multirow{2}{*}{$\begin{array}{l}\text { Community } \\
\text { pressure }\end{array}$} & $\begin{array}{l}\text { 1. The community is interested in the enviro } \\
\text { nmental report of the organization }\end{array}$ & CP1 & \multirow{2}{*}{$\begin{array}{l}\text { Deegan \& Rankin (1996); Liu and Anbumozhi (200 } \\
\text { 9); Patten (1992); Qian, Burritt, \& Monroe (2011); } \\
\text { Tilt (1994) }\end{array}$} \\
\hline & & $\begin{array}{l}\text { 2. Community increases awareness of } \\
\text { environmental impacts }\end{array}$ & $\mathrm{CP} 2$ & \\
\hline \multirow{4}{*}{7} & \multirow{4}{*}{$\begin{array}{l}\text { Pressure from } \\
\text { stakeholders }\end{array}$} & 1. The shareholders of the company & SP 1 & \multirow{4}{*}{$\begin{array}{l}\text { Deegan \& Gordon (1996); Jamil, Mohamed, Muham } \\
\text { mad, \& Ali (2015) }\end{array}$} \\
\hline & & 2. Customers & SP 2 & \\
\hline & & 3. Newspapers and media & SP 3 & \\
\hline & & 4. Environmental organizations & SP 4 & \\
\hline \multirow{6}{*}{8} & \multirow{6}{*}{$\begin{array}{l}\text { Government } \\
\text { pressure (GP) }\end{array}$} & $\begin{array}{l}\text { 1. Regulations on government environmental } \\
\text { report }\end{array}$ & GP 1 & \multirow{6}{*}{$\begin{array}{l}\text { DiMaggio \& Powell (1983); Pondeville, Swaen, \& R } \\
\text { ongé (2013); Qian, Burritt, \& Monroe (2011) }\end{array}$} \\
\hline & & $\begin{array}{l}\text { 2. Tighten the granting of environmental } \\
\text { licenses }\end{array}$ & GP 2 & \\
\hline & & 3. Regulations on environmental penalties & GP 3 & \\
\hline & & 4. National/international environmental law & GP 4 & \\
\hline & & 5. Environmental tax policy & GP 5 & \\
\hline & & $\begin{array}{l}\text { 6. Environmental regulations affecting the in } \\
\text { dustry }\end{array}$ & GP 6 & \\
\hline
\end{tabular}

\section{3. Data Collection Methods}

\subsubsection{Determine the Sample Size Collected for the Study}

According to the economic subdivision in Vietnam, there are three business sectors according to the business areas including: agriculture - forestry and fisheries, industry and construction, trade and services. With the research method of EFA discovery factor analysis, according to Hair, Black, Babin, and Anderson (2010), the sample size is determined 
based on (1) Minimum sample size $(\min =50)$ and (2) Number of variables taken into analysis of the model according to the formula:

n: Sample size

m: Number of scales

$\mathrm{k}$ : The ratio of the sample to an analytical variable (5/1 or 10/1)

$\mathrm{Pj}$ : Number of observed variables of the $\mathrm{j}$-th scale

The research model of this paper is expected to have 8 scales, each scale has from 1 to 6 variables, the total of 20 variables, an average of 2.5 variables for each scale, choose the sample rate per an analytical variable of 5/1, applying the above formula of Hair, Black, Babin, and Anderson (2010), we have the minimum sample size of 100 enterprises to be surveyed, to ensure that the number of valid votes collected is more than 100 votes, the authors equally divided for each business area. Then, each sector would have 40 votes, and the number of questionnaires of the study is 120 , in which 106 enterprises returned valid questionnaires, accounting for the rate is $88.33 \%$, meeting the required number of research votes.

\subsubsection{Way to Collect Data}

In order to assess the factors affecting the disclosure of environmental information, the authors use the survey method with questionnaires, sent directly or via the Google Form tool to the chief accountant or director of the listed companies. The survey questionnaire is designed with 2 parts, part 1 covers general information of participants and part 2 covers survey questions. Survey questions are designed around research objectives, requiring respondents to evaluate based on Likert scale from 1 to 5 .

In order to have an official survey questionnaires, the authors have carried out 3 stages: stage 1, based on the research overview, the authors designed the initial draft questionnaire; stage 2, consult experts (10 experts) and conduct a preliminary survey (10 listed companies) to ensure that the questions in the survey are complete and appropriate to the Vietnamese context and have a clear and understandable style; stage 3 , designed the official questionnaire, based on the results in stage 2, the authors synthesize and gives the final complete questionnaire to send to the survey subjects.

\subsection{Methods of Data Analysis}

After collecting all the data, the authors translate into Excel, coding the variables in each part of the questionnaire. Next, put all data into SPSS 22.0 software. In the process of data processing and analysis, the authors have conducted a number of analysis and verification tools on SPSS software as follows:

Descriptive statistics and Average value verification:
Using descriptive statistics to calculate the average value for factors affecting environmental information disclosure. Also, check the average value to evaluate the average of the factors compared to the average value of 3 , to see the influence of the factors.

Cronbach's Alpha analysis: The purpose of Cronbach's Alpha analysis is to test scale reliability and survey data to assess the correlation between observed variables which are the influencing factors in the survey questionnaire to see whether observed variables are closely related to each other in measuring the impact of inspection factors on environmental information disclosure. Most researchers accept Cronbach's Alpha levels of 0.8 or higher; 0.7 to 0.8 is usable and if the concepts in the question are new, the coefficient is just above 0.6.

With Cronbach's Alpha level greater or equal to 0.8, the scale is considered good measurement, the questions are designed strictly, the scales are really correlated to achieve high-reliability Chu and Hoang (2011). The elimination of variables also follows the Cronbach's Alpha coefficient principle that the coefficient eliminated will actually be larger than the overall Cronbach's Alpha coefficient. When Cronbach's Alpha is $>0.6$, the scale is acceptable in terms of reliability.

EFA exploratory factor analysis: When analyzing discovery factors, researchers often care about some standards. First, KMO coefficient (Kaiser-Meyer-Olkin) $\geq$ 0.5 , the significance level of Bartlett $\leq 0.05$ test. $\mathrm{KMO}$ is a criterion used to consider the appropriateness of EFA, $0.5 \leq$ $\mathrm{KMO} \leq 1$, then factor analysis is appropriate. Bartlett's Test examined the hypothesis of the correlation between zero observed variables in the overall. If this test is statistically significant $(\mathrm{Sig} \leq 0.05)$, the observed variables are correlated in the overall.

Second, Factor loading coefficient $>0.45$. If any observed variable has factor loading coefficient $\leq 0.45$, it will be disqualified. Third, the scale is accepted when the total variance extracted $\geq 50 \%$ and eigenvalue is greater than 1. The fourth criterion is the difference in factor loading coefficient of an observed variable among factors $\geq$ 0.3 to ensure the distinguishing value among factors is protected (Chu \& Hoang, 2011). According to Dinh, Vo, and Tran (2018), Factor loading is the norm to ensure the practical meaning of EFA, Factor loading $>0.3$ is considered to be the minimum, Factor loading $>0.4$ is considered Important, $\geq 0.5$ is considered to have practical significance.

\section{Research Results}

\subsection{Verification of Reliability}


In this study, observed variables of independent variables and dependent variables are selected when Cronbach's Alpha coefficient is 0.6 or higher and the total correlation coefficient is greater than 0.3 . The results in Table 3 show that the variables in the research model are reliable.

Table 3: The Cronbach's Alpha coefficient of the independent variable and the dependent variable

\begin{tabular}{|c|c|c|}
\hline Reliability Statistics & Cronbach's Alpha & N of Items \\
\hline Y &, 911 & 4 \\
\hline ABM &, 920 & 4 \\
\hline CP &, 887 & 2 \\
\hline SP &, 875 & 4 \\
\hline GP &, 896 & 6 \\
\hline
\end{tabular}

\subsection{Exploratory Factor Analysis (EFA)}

\subsubsection{Exploratory Factor Analysis for Independent Variables}

When we analyze the exploratory factor of EFA for independent variables (20 factor variables affecting environmental information disclosure) gave $\mathrm{KMO}$ results = $0.865>0.5 ; \mathrm{Sig}=0,000<0.05 ;$ variance extracted $=$ $76.718 \%>50 \%$; loading factor of the observed variables $>$ 0.5 . Thus, factor exploratory analysis for independent variables is appropriate, 20 independent variables explain $76.718 \%$ of data variability through observed variables (Source: collected from research results).

\subsubsection{Exploratory Factor Analysis for Dependent Variables}

When analyzing the factor of exploratory EFA for dependent variable (environmental information disclosure) by SPSS software 22.0, it shows that KMO $=0.914>0.5$; Sig $=0,000<0.05$; variance extracted $69.765 \%>50 \%$, loading factor of observed variables $>0.5$. Thus, the exploratory factor analysis for the dependent variable is appropriate, the dependent variable explains $69.765 \%$ of the data variability through observed variables (Source: collected from research results).

\subsection{Regression Analysis}

In order to establish multivariate regression functions, it is necessary to first evaluate the relationship between the dependent variable and the independent variable. The greater the correlation coefficient, the stronger the relationship between variables and vice versa. Simultaneously, if the correlation coefficient is positive, the pairs of variables are positively correlated, and if the correlation coefficient is negative, pairs of variables have an inverse relationship. Table 4 and Table 5 show the results of checking the factors affecting the environmental information disclosure of listed companies in Vietnam stock market.

Table 4: Results of the regression model

\begin{tabular}{|c|c|c|c|c|c|}
\hline Model & R & R Square & $\begin{array}{c}\text { Adjusted } \\
\text { R Square }\end{array}$ & F & Sig. \\
\hline 1 & $0,918^{\mathrm{a}}$ & 0,841 & 0,832 & 91,418 & $0,000^{\mathrm{b}}$ \\
\hline
\end{tabular}

Table 5: Regression coefficient

\begin{tabular}{|c|c|c|c|c|c|c|c|c|}
\hline & \multirow{2}{*}{ Model } & \multicolumn{2}{|c|}{ Unstandardized Coefficients } & \multirow{2}{*}{$\begin{array}{c}\text { Standardized Coefficients } \\
\text { Beta }\end{array}$} & \multirow{2}{*}{$\mathbf{T}$} & \multirow{2}{*}{ Sig. } & \multicolumn{2}{|c|}{ Collinearity Statistics } \\
\hline & & B & Std. Error & & & & Tolerance & VIF \\
\hline \multirow[t]{9}{*}{1} & (Constant) & -1.943 & 0.215 & & -6.231 & 0.000 & & \\
\hline & $\mathrm{BS}$ & 0.209 & 0.028 & 0.440 & 7.644 & 0.000 & $0 ; 712$ & 1.154 \\
\hline & $\mathrm{CS}$ & 0.324 & 0.029 & 0.191 & 8.684 & 0.000 & 0.753 & 1.325 \\
\hline & ABM & 0.328 & 0.026 & 0.051 & 1.141 & 0.023 & 0.644 & 1.642 \\
\hline & $\mathrm{P}$ & -0.196 & 0.023 & -0.110 & -.948 & 0.000 & 0.863 & 1.245 \\
\hline & FL & -0.121 & 0.031 & -0.024 & -.721 & 0.412 & 0.713 & 1.311 \\
\hline & $\mathrm{CP}$ & 0.235 & 0.029 & 0.177 & 4.624 & 0.000 & 0.744 & 1.361 \\
\hline & SP & 0.427 & 0.032 & 0.511 & 12.417 & 0.000 & 0.642 & 1.512 \\
\hline & GP & 0.529 & 0.039 & 0.456 & 13.476 & 0.000 & 0.867 & 1.763 \\
\hline
\end{tabular}

Thus, the Sig value of F-test is $0,000<0.05$, indicating that the linear regression model is suitable for the whole. The corrected coefficient R2 in Table 4 is 0.832 which means that the independent variables in the model explained $83.2 \%$ of the change of environmental information disclosure, the model has achieved a high degree of conformity. All values of Sig in Table 5 are less than or equal to 0.05 that implies all these independent variables are meaningful for the dependent variable, and if it is greater than 0.05 , the variable will be rejected. Therefore, the "FL" variable with sig equal to 0.412 is removed from the research model. Thus, reject the hypothesis $\mathrm{H} 5$.

The analysis of the Beta standardized regression coefficients in Table 5 shows the degree of impact of the independent variables on the dependent variable. In the remaining 7 independent variables, except for one independent variable, $\mathrm{P}$ which has a negative correlation, showing an inverse relationship, 6 other independent environmental information disclosure, in which: "GP" (Beta $=0.529)$ has the strongest impact, followed by "SP" ((Beta $=0.427)$, followed by "ABM" (Beta $=0.328)$, "CS" ( Beta 
$=0.324)$, "CP" (Beta $=0.235)$, and the lowest is "BS" (Beta $=0.209$ ).

Thus, hypotheses $\mathrm{H} 1, \mathrm{H} 2, \mathrm{H} 3, \mathrm{H} 4, \mathrm{H} 6, \mathrm{H} 7, \mathrm{H} 8$ are accepted. In addition, VIF coefficients in Table 5 of the variables are less than 2 (for research with models and questionnaires using Likert scale), so there is no multi-line phenomenon occurs. So the official regression equation is as follows:

$\mathrm{Y}=-1.943+0.209 \times \mathrm{BS}+0.324 \times \mathrm{CS}+0.328 \times \mathrm{ABM}-$ $0.196 \times \mathrm{P}+0.235 \times \mathrm{CP}+0.427 \times \mathrm{SP}+0.529 \times \mathrm{GP}$

\section{Discussion}

This study has shown that, in Vietnam, regulations, legal documents from the government, environmental management agencies have the strongest influence on environmental information disclosure; followed by pressure from stakeholders such as environmental protection organizations, environmental interdisciplinary management agencies, which is consistent with the research of Deegan and Gordon (1996); followed by the perception of company governance on the implementation of environmental information accountability to meet government needs and related parties' requirements, which is consistent with studies that senior management awareness has a positive impact on environmental disclosure behavior of enterprises such as Kokubu and Nashioka (2005); Lee, Jung, and Kim (2005); Liu and Anbumozhi (2009); Zeng, Xu, Yin, and Tam (2012); Wilmshurst and Frost (2000).

At the same time, the enterprise size is also a significant influence on environmental information disclosure activities of listed companies on Vietnam's stock market; because the larger the companies size, the more financial and technical resources the enterprise has to implement environmental information disclosure, and the long-term strategic vision of the environment; therefore, it is easier for companies to implement changes in environmental accounting activities to publish more environmental information in order to build the image and position of the enterprise. This research result is consistent with some previous studies such as Deegan and Gordon (1996); Hackston and Milne (1996); Patten (1992); Zhang, Guo, Li, and Wang (2008); etc., see enterprise size as a decisive factor for environmental information disclosure.

The study also shows that the factors of community pressure, business sector have positive impact on environmental information disclosure, which is consistent with the research results of previous researchers. Although the degree of influence is different for businesses in Vietnam. However, unlike previous studies Saha and Akter (2012); Zhang, Guo, Li, and Wang (2008) research has proved in Vietnam, profitability and environmental information disclosure have reverse relations; Our in-depth interview also showed that most businesses view environmental information disclosure as a mandatory task to comply with state legal documents, there are very few enterprises focusing on transparent information, attracting investment or even doubting the profitability of companies which can be obtained from environmental information disclosure.

\section{Conclusion}

This study has shown that factors including internal and external companies have an impact on environmental information disclosure and the impact level of each factor through Cronbach's Alpha test, Exploratory Factor Analysis (EFA), regression analysis based on a survey of 120 listed companies in the stock market in Vietnam. The factors that impact positively include: the force of pressure from the government has the strongest impact, followed by pressure from stakeholders, awareness of company managers, company size, community pressure and business sector; while the profitability and financial leverage factor is inversely related to environmental information disclosure.

From the research results, it is important for the Government of Vietnam to issue regulations on the publication of environmental information, environmental accounting, compliance with environmental laws and regulations to promote environmental information disclosure of listed companies on the stock market in Vietnam; Therefore, the Government of Vietnam and environmental authorities should soon complete and enact environmental accounting standards, environmental practice circulars, and environmental reporting frameworks, and legal documents and other necessary sanctions in accordance with international practice of environmental information disclosure.

The authors realize that, with the survey and investigation through questionnaires for listed companies on Ho Chi Minh City Stock Exchange (HOSE), it is impossible to get a general or probable conclusion about the factors affecting the environmental information disclosure of listed companies in the stock market in Vietnam. Despite the above-mentioned limitations, the authors of the paper still maintains that this research has contributed to the review of the research on factors affecting environmental information disclosure in Vietnam, a problem which is still very new and controversial in Vietnam; and we believe that the results of our research can be considered as a starting point for other studies in the future if the research sample size is expanded, focusing on sensitive industries, etc to identify factors affecting the environmental information 
disclosure of companies in Vietnam.

\section{References}

Aerts, W., Cormier, D., \& Magnan, M. (2008). Corporate environmental disclosure, financial markets and the media: An international perspective. Ecological Economics, 64(3), 643-659. https://doi.org/10.1016/j.ecolecon.2007.04.012.

Bebbington, J., Gray, R., Thomson, I., \& Walters, D. (1994). Accountants' Attitudes and Environmentallysensitive Accounting. Accounting and Business Research, 24(94), 109-120. https://doi.org/10.1080/00014788.1994.9729470.

Cadez, S., \& Guilding, C. (2008). An exploratory investigation of an integrated contingency model of strategic management accounting. Accounting, Organizations and Society, 33(7-8), 836-863. https://doi.org/10.1016/j.aos.2008.01.003.

Chenhall, R. H. (2003). Management control systems design within its organizational context: findings from contingency-based research and directions for the future. Accounting, Organizations and Society, 28(2-3), 127168. https://doi.org/10.1016/S0361-3682(01)00027-7.

Chu, N. N., \& Hoang, T. (2011). Applied Statistics in Social- Economic Analysis. Hanoi, Vietnam: Labour and Social Publising House.

Cormier, D., \& Gordon , I. M. (2001). An examination of social and environmental reporting strategies. Accounting, Auditing \& Accountability Journal, 14(5), 587-617. https://doi.org/10.1108/EUM0000000006264.

Deegan, C., \& Gordon, B. (1996). A Study of the Environmental Disclosure Practices of Australian Corporations. Accounting and Business Research, 26(3), 187-199.

https://doi.org/10.1080/00014788.1996.9729510.

Deegan, C., \& Rankin, M. (1996). Do Australian companies report environmental news objectively? An analysis of environmental disclosures by firms prosecuted successfully by the Environmental Protection Authority. Accounting, Auditing \& Accountability Journal, 9(2), 50-67. https://doi.org/10.1108/09513579610116358.

Deegan, C., Rankin, M., \& Tobin, J. (2002). An examination of the corporate social and environmental disclosures of BHP from 1983-1997. Accounting, Auditing \& Accountability Journal, 15(3), 312-343. https://doi.org/10.1108/09513570210435861.

DiMaggio, P. J., \& Powell, W. W. (1983). The Iron Cage Revisited: Institutional Isomorphism and Collective Rationality in Organizational Fields. American
Sociological Review, 48(2), 147-160. doi: 10.2307/2095101.

Dinh, H. P., Vo, N. V., \& Tran, P. (2018). Quantitative research in Accounting - Auditing. Hanoi, Vietnam: Financial Publishing House.

Gelb, D. S., \& Zarowin, P. (2002). Corporate Disclosure Policy and the Informativeness of Stock Prices. Review of Accounting Studies, 7(1), 33-52. Retrieved from https://link.springer.com/article/10.1023/A:1017927530 007.

Gray, R., Kouhy, R., \& Lavers, S. (1995). Corporate social and environmental reporting. Accounting, Auditing \& Accountability Journal, 8(2), 47-77. https://doi.org/10.1108/09513579510146996.

GRI. (2018). The global standards for sustainability reporting. Retrieved September, 10 2019, from https://www.globalreporting.org/information/sustainabil ity-reporting/Pages/default.aspx

Guthrie, J., \& Parker, L. D. (1990). Corporate social disclosure practice: a comparative international analysis. Advances in Public Interest Accounting, 3, 159-175.

Hackston, D., \& Milne, M. (1996). Some determinants of social and environmental disclosures in New Zealand companies. Accounting, Auditing \& Accountability Journal, $\quad 9(1), \quad$ 77-108. https://doi.org/10.1108/09513579610109987.

Hair, J. F., Black, W. C., Babin, B. J., \& Anderson, R. E. (2010). Multivariate Data Analysis. (7th ed.). Upper Saddle River, NJ: Prentice Hall.

Haldma, T., \& Lääts, K. (2002). Contingencies influencing the management accounting practices of Estonian manufacturing companies. Management Accounting Research, 13(4), 379-400. https://doi.org/10.1006/mare.2002.0197.

Huang, C.-L., \& Kung, F.-H. (2010). Drivers of Environmental Disclosure and Stakeholder Expectation: Evidence from Taiwan. Journal of Business Ethics, 96(3), 435-451. doi: 10.1007/s10551-010-0476-3.

Jamil, C. Z., Mohamed, R., Muhammad, F., \& Ali, A. (2015). Environmental management accounting practices in small medium manufacturing firms. Procedia - Social and Behavioral Sciences, 172, 619626. doi: 10.1016/j.sbspro.2015.01.411.

Kokubu, K., \& Nashioka, E. (2005). Environmental Management Accounting Practices in Japan. In EcoEfficiency in Industry and Science, 18 (pp. 321-342). New York, NY: Springer.

Lee, B.-W., Jung, S.-T., \& Kim, J.-H. (2005). Environmental Accounting Guidelines and Corporate Cases in Korea. In K. Sustainable Management Division of LG Environmental Strategy Institute (LGESI), Implementing Environmental Management 
Accounting: Status and Challenges (pp. 239-255). doi: 10.1007/1-4020-3373-7_12.

Lee, J. W., Kim, Y. M., \& Kim, Y. E. (2018). Antecedents of Adopting Corporate Environmental Responsibility and Green Practices. Journal of Business Ethics, 148(2), 397-409. doi: 10.1007/s10551-016-3024-y.

Lehman, C. R. (1983). Stalemate in corporate social responsibility research (working paper, no. 3). American Accounting Association. Public Interest Section, American Accounting Association.

Li, Y., Richardson, G. D., \& Thornton, D. B. (1997). Corporate Disclosure of Environmental Liability Information: Theory and Evidence. Contemporary Accounting Researc, 14(3), 435-474. https://doi.org/10.1111/j.1911-3846.1997.tb00535.x.

Liu, X., \& Anbumozhi, V. (2009). Determinant factors of corporate environmental information disclosure: An empirical study of Chinese listed companies. Journal of Cleaner Production, 17(6), 593-600. doi: 10.1016/j.jclepro.2008.10.001.

Malarvizhi, P., \& Matta, R. (2016). Link between Corporate Environmental Disclosure and Firm Performance" - Perception or Reality? Review of Integrative Business and Economics Research, 5(3), 134. Retrieved from http://www.sibresearch.org/uploads/3/4/0/9/34097180/ri ber_b16-033_1-34.pdf.

Ministry of Finance. (2015, 10 6). Circular 155-2015-TTBTC on disclosure of information on the securities market. Retrieved September 15, 2019, from https://vbpq.mof.gov.vn/Detail?contentType=LegalDoc ument\&id $=19070 \&$ tab $=99$

Ministry of Natural Resources and Environment. (2019). Circular No. 38/2015/TT-BTNMT dated 30 June 2015, on environmental remediation and restoration in mineral mining activities. Retrieved September 10, 2019,

from http://vanban.chinhphu.vn/portal/page/portal/chinhphu/ hethongvanban?class_id $=1 \&$ mode $=$ detail\&document_i $\mathrm{d}=180819$

National Assembly of the Socialist Republic of Vietnam. (2014, June 23). Law No. 55/2014/QH13 dated June 23, 2014, on environmental protection. Retrieved October 20, 2018, from http://vanban.chinhphu.vn/portal/page/portal/chinhphu/ hethongvanban

Neu, D., Warsame, H., \& Pedwell, K. (1998). Managing Public Impressions: Environmental Disclosures in Annual Reports. Accounting, Organizations and Society, 23(3), 265-282. https://doi.org/10.1016/S03613682(97)00008-1.

Patten, D. M. (1992). Intra-industry environmental disclosures in response to the Alaskan oil spill: A note on legitimacy theory. Accounting, Organizations and Society, 17(5), 471-475. https://doi.org/10.1016/03613682(92)90042-Q.

Patten, D. M. (2002). The relation between environmental performance and environmental disclosure: a research note. Accounting, Organizations and Society, 27(8), 763-773. https://doi.org/10.1016/S03613682(02)00028-4.

Pondeville, S., Swaen, V., \& Rongé, Y. D. (2013). Environmental management control systems: The role of contextual and strategic factors. Management Accounting Research, 24, 317-332. http://dx.doi.org/10.1016/j.mar.2013.06.007.

Qian, W., Burritt, R., \& Monroe, G. (2011). Environmental management accounting in local government. Accounting, Auditing \& Accountability Journal, 24(1), 93-128. https://doi.org/10.1108/09513571111098072.

Robertson, D. C., \& Nicholson, N. (1996). Expressions of corporate social responsibility in U.K. firms. Journal of Business Ethics, 15(10), 1095-1106. Retrieved from https://www.jstor.org/stable/25072834.

Saha, A. K., \& Akter, S. (2012). Relationship between Environmental Reporting in Corporate Annual Reports \& Corporate Profitability in Bangladesh. Independent Business Review, 5(2), 91-111. Retrieved from https://ssrn.com/abstract=2435563.

Shane, P. B., \& Spicer, B. H. (1983). Market Response to Environmental Information Produced outside the Firm. The Accounting Review, 58(3), 521-538. Retrieved from https://www.jstor.org/stable/246532.

Spencer, S. Y., Adams, C., \& Yapa, P. W. (2013). The mediating effects of the adoption of an environmental information system on top management's commitment and environmental performance. Sustainability Accounting, Management and Policy Journal, 4(1), 75102. https://doi.org/10.1108/SAMPJ-10-2011-0030.

Tilt, C. A. (1994). The Influence of External Pressure Groups on Corporate Social Disclosure. Accounting, Auditing \& Accountability Journal, 7(4), 47-72. https://doi.org/10.1108/09513579410069849.

United Nations. (2002). Guidance manual accounting and financial reporting for environmental costs and liabilities. United Nations Conference on Trade and Development (pp. 5-14). Retrieved from https://unctad.org/en/Docs/iteeds4c1_en.pdf.

Wilmshurst, T. D., \& Frost, G. R. (2000). Corporate environmental reporting. Accounting, Auditing \& Accountability Journal, 13(1), 10-26. https://doi.org/10.1108/09513570010316126.

Wiseman, J. (1982). An evaluation of environmental disclosures made in corporate annual reports. Accounting, Organizations and Society, 7(1), 53-63. https://doi.org/10.1016/0361-3682(82)90025-3. 
Yale University. (2018). Environmental Performance Index. Retrieved August 12, 2019, from https://epi.envirocenter.yale.edu/downloads/epi2018poli cymakerssummaryv01.pdf

Zeng, S. X., Xu, X. D., Yin, H. T., \& Tam, C. M. (2012). Factors that Drive Chinese Listed Companies in Voluntary Disclosure of Environmental Information.
Journal of Business Ethics, 109(3), 309-321. Retrieved from https://www.jstor.org/stable/23257154.

Zhang, J., Guo, H. T., Li, B., \& Wang, W. (2008). The Influence of Financial Factors on Environmental Information Disclosure in China Chemical Industry. SSRN, 01-12. Retrieved from https://ssrn.com/abstract=1305005 or http://dx.doi.org. 